\title{
Potential therapeutic uses of interleukin 1 receptor antagonists in human diseases
}

\section{S Hallegua, M H Weisman}

See end of article for authors' affiliations

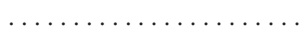

Correspondence to: Dr M H Weisman,

Cedars-Sinai Medical

Center, Department of

Rheumatology, 8700

Beverly Blvd, Los Angeles,

CA 90048, USA;

weisman@cshs.org

Accepted 11 April 2002

\begin{abstract}
Objective: To review publications relating to the blocking of interleukin 1 (IL 1) as a strategy for treating human disease, ranging from rheumatoid arthritis (RA) to Alzheimer's disease.

Methods: The National Library of Medicine's PubMed database was searched for articles about pharmaceutical agents that reduce the biological actions of IL 1 .

Results: Fish oils and corticosteroids were identified as non-selective pharmacological interventions that reduce the activity of IL 1, whereas a recombinant human IL 1 receptor antagonist (anakinra) and a soluble recombinant type I IL I receptor act selectively. To date, anakinra is the only selective intervention that has been shown in controlled clinical trials to be effective and well tolerated in the treatment of a specific human disorder, RA. In controlled clinical trials, anakinra provided significant clinical improvement and slowed radiographic disease progression in patients with active RA. Moreover, addition of anakinra to existing methotrexate treatment significantly reduced signs and symptoms of active disease.

Conclusions: The clinical use of anakinra has been demonstrated in the management of RA, but blocking of ILI in other human disorders, as well as the safety of the use of these blocking agents in chronic diseases, still needs to be defined by controlled clinical investigations.
\end{abstract}

$\mathrm{T}$ he cytokines interleukin 1 (ILl) and tumour necrosis factor $\alpha(\mathrm{TNF} \alpha)$ are produced acutely as part of host defence in response to microbial infection, inflammation, and tissue injury. ${ }^{1-4}$ Overexpression of these cytokines, however, has been implicated in the pathogenesis of several human diseases-notably, rheumatoid arthritis (RA) and other chronic inflammatory disorders, including Crohn's disease. Accordingly, agents capable of blocking these cytokines have been sought for their potential clinical use. Advances made in the laboratory looking at cytokine regulation as a means of reducing immune cell activity have been rapidly translated into the clinical setting. The efficacy and safety of several biological agents that block either ILl or TNF $\alpha$ have now been established in controlled clinical trials, mostly in patients with RA but also in Crohn's disease. . $^{5-13}$

The efficacy of TNF blocking agents etanercept and infliximab confirms a large body of experimental evidence that implicated TNF $\alpha$ in the pathogenesis of chronic inflammatory diseases. In addition, a large amount of experimental evidence supports a role for ILl in these disorders. Moreover, in each clinical trial, a significant percentage of patients did not respond adequately to the TNF blockers, suggesting that TNF $\alpha$ alone cannot explain the pathogenesis of chronic inflammatory disease. Further, a role for ILl in RA is supported by results of controlled clinical trials of anakinra, a recombinant human ILl receptor antagonist (ILIRa). ${ }^{14}{ }^{15}$ This paper will focus on blocking ILl as a therapeutic strategy for human disease.

\section{STRUCTURE AND FUNCTION OF IL1 AND RELATED MOLECULES}

ILl exists in two forms-ILl $\alpha$ and ILl $\beta .{ }^{12}$ Each is produced by a separate gene as a $31 \mathrm{kDa}$ precursor protein, termed proILl $\alpha$ and proILl $\beta$, respectively. The proILl forms are subsequently cleaved by specific cellular proteases, including ILl converting enzyme, into mature $17 \mathrm{kDa}$ proteins. ILl $\alpha$ is generally located intracellularly or expressed on the cell surface; it is believed to function as an autocrine messenger. In contrast, ILl $\beta$ is released from the cell and produces its effects by acting on other cells. ILIRa is the third member of the ILI family; it is produced and secreted as a $17 \mathrm{kDa}$ protein by almost all cells that express ILl. ${ }^{16}$ Although each of the ILl family members has a distinct amino acid sequence, their three dimensional structures are related, and consequently, each can bind with high affinity to ILl receptors located on target cells.

The members of the ILl family can bind to two distinct ILl receptors, termed type I (ILIRI) and type II (ILIRII). ${ }^{2}$ Binding of ILl $\alpha$ or IL1 $\beta$ to ILIRI leads to receptor activation and subsequent intracellular signal transduction and cellular responses (fig 1). In contrast, ILIRII contains a short cytoplasmic domain and is unable to transduce an intracellular signal in response to ILl binding. Therefore, IL1RI is the receptor that mediates the biological actions of ILl, whereas ILIRII is a decoy receptor that may serve to buffer the effects of excessive ILl concentrations. The extracellular domains of both receptors are found in the circulation in both healthy and disease states, where these soluble fragments may also function to buffer the actions of ILl. Whereas ILl $\alpha$ and ILI $\beta$ may be considered as agonists at the ILIRI, the third member of the ILl family, ILIRa, functions as a competitive receptor antagonist. ILlRa blocks binding of ILl $\alpha$ and ILI $\beta$ to ILIRI, thereby preventing ILIRI activation and inhibiting the biological actions of ILl (fig l).

ILl produces a variety of biological actions that appear conserved across species. ${ }^{2}{ }^{17}$ Systemic injection of recombinant ILl elicits fever, increased slow wave sleep, anorexia, hypotension, leucopenia, and thrombocytopenia. ILl stimulates the hypothalamic-pituitary-adrenal axis, leading to production of adrenocorticotrophic hormone, growth hormone, vasopressin,

Abbreviations: $C R P, C$ reactive protein; $E S R$, erythrocyte sedimentation rate; IL 1, interleukin I; ILIRa, ILI receptor antagonist; NSAID, non-steroidal anti-inflammatory drug; $\mathrm{OA}$, osteoarthritis; $\mathrm{PGE}_{2}$, prostaglandin $\mathrm{E}_{2} ; \mathrm{RA}$, rheumatoid arthritis; sILIR, soluble ILI receptor; TNF $\alpha$, tumour necrosis factor $\alpha$ 


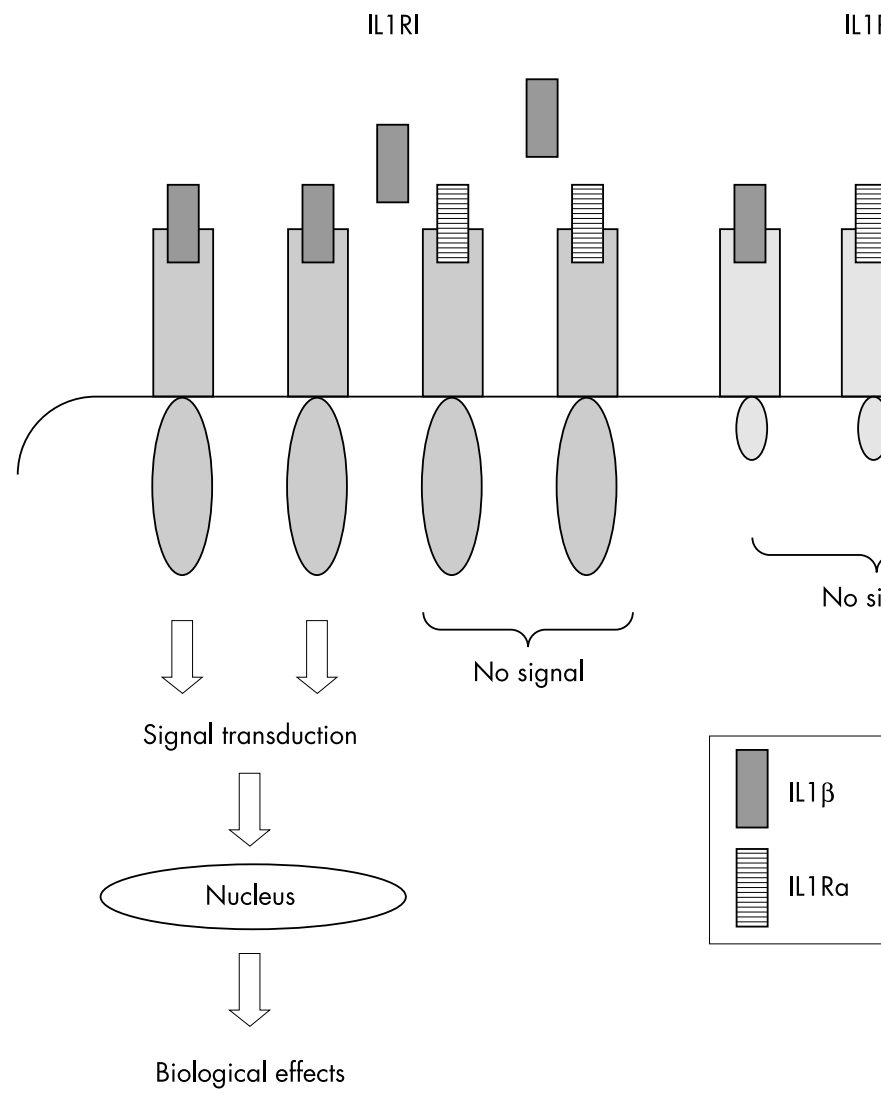

and somatostatin. ILl influences haemopoiesis by increasing production of colony stimulating factors and stem cell factors and by acting synergistically with these factors to augment production of granulocytes and platelets. ILl may also protect the haemopoietic progenitors against the damaging effects of radiation and cytotoxic drugs. ILl stimulates production of acute phase proteins by the liver, including IL6, fibrinogen, complement components, and various clotting factors. ILl also protects against infection in normal and compromised animals provided that it is present before the onset of the pathological process.

On a cellular level, ILl regulates the expression of numerous genes that are involved in inflammatory and immune responses. ${ }^{217}$ For example, ILl increases expression of intercellular cell adhesion molecule-1 (ICAM-1) and vascular cell adhesion molecule-1 (VCAM-1) on endothelial cells, which facilitate leucocyte entry into inflammatory sites. ILl also induces expression of enzymes which play a part in the synthesis of proinflammatory mediators, such as nitric oxide, prostaglandins, and platelet activating factor. ILl triggers $\mathrm{T}$ and B lymphocyte activation, leading to generation of numerous cytokines, increased antibody production, and expansion of specific T cell clones. In joints, ILl stimulates chondrocytes to release collagenase and other proteolytic enzymes involved in cartilage degradation. ILl also stimulates the differentiation of osteoclast progenitors and subsequently contributes to the activation of mature osteoclasts, leading to bone resorption. Finally, ILl triggers growth factor release, leading to proliferation of fibroblasts and smooth muscle cells.

In normal homoeostasis, the actions of ILl are maintained in balance by ILIRa, other natural ILl inhibitors, such as ILIRII and circulating soluble ILIRI and ILIRII, as well as a network of anti-inflammatory cytokines. However, increased ILl production has been reported in a variety of disease states, including autoimmune diseases, infection, solid tumours, leukaemia, Alzheimer's disease, trauma, haemodialysis, ischaemic myocardial infarction, asthma, and graft versus host disease. ${ }^{2}$ In RA, for example, systemic and synovial fluid concentrations of ILl are raised, and they correlate with disease severity and histological features. ${ }^{18}{ }^{19}$ ILIRa levels are also increased in many patients with RA, but they may not be sufficient for keeping ILl activity in balance. ${ }^{20} 21$

\section{ANIMAL MODELS \\ Role of ILIRa}

The importance of ILIRa in homoeostasis can be gleaned from studies of knockout mice in which the ILlRa gene was deleted. Inflammatory erosive arthritis developed spontaneously in mice with a BALB/cA genetic background, but it occurred at a much lower incidence in mice with a C57BL background..$^{22}$ The polyarthropathy was characterised by pannus invasion of the articular surface and histological evidence of marked synovial and periarticular inflammation, resembling the inflammatory changes typically seen in RA. Evidence of autoimmune disease was suggested by the presence of antibodies against type II collagen, immunoglobulins, and double stranded DNA. The expression of ILl and several other proinflammatory cytokines was also increased, reflecting an imbalance in the normal cytokine network. In another study, deletion of the IL1Ra gene led to development of lethal arteritis with aneurysm formation. ${ }^{23}$ Arterial inflammation was found at branch points and flexures of the aorta as well as its primary and secondary branches. Histologically, massive infiltration of neutrophils, macrophages, and CD4+ T lymphocytes was found in these arterial lesions.

Neutralising anti-ILIRa antibodies have also been used to evaluate the role of endogenous ILIRa in acute inflammatory states. For example, immune colitis in rabbits depends on production of ILl in the colon and is ameliorated by exogenous administration of IL1Ra. ${ }^{24}$ This model is characterised by neutrophil and eosinophil infiltration, crypt abscess formation, epithelial cell degeneration, mucous depletion, and mucosal necrosis. Colonic ILl levels increase initially before 
the onset of inflammation, and then 48 hours later, ILIRa levels rise, preceding a significant decline in ILl and resolution of the colonic inflammation. However, administration of antiILl Ra resulted in exacerbation and prolongation of the colonic inflammation, and it proved lethal in six of 18 animals. In contrast, all control animals survived. Moreover, colonic ILl levels were significantly increased by anti-IL1Ra treatment. This study suggests that endogenous ILIRa plays a protective role against inflammatory insults.

\section{Role of IL1}

The role of ILl in various disease models in animals has been inferred by the protective effects of recombinant ILlRa, soluble ILl receptors ( ILIR), and neutralising antibodies to ILl $\alpha$ and IL1 $\beta$. Blocking the effects of endogenous ILl with these agents improved survival in mice and rabbits injected with endotoxin; reduced shock in rabbits and baboons with bacteraemia; reduced the incidence and severity of inflammatory arthritis in mice, rats, and rabbits; reduced colonic inflammation in rats and rabbits; decreased the severity of graft versus host disease and prolonged survival of cardiac allografts in mice; inhibited experimental autoimmune encephalomyelitis in mice and ischaemic brain injury in rats; diminished the late phase asthmatic response and airway hyperreactivity in guinea pigs; reduced lung injury in rats; decreased glomerulonephritis in rats; and inhibited streptozotocin induced diabetes in mice. ${ }^{16}$. Although a description of each of these studies is beyond the scope of this article, the collagen induced arthritis model in mice illustrates the therapeutic benefit of blocking ILl. Administration of neutralising antibodies to ILl $\alpha$ and ILl $\beta$ before the onset of arthritis prevented or delayed the appearance of disease, and in those animals that developed arthritis, it was characterised by only mild symptoms. $^{26}$ Moreover, administration of anti-ILl $\alpha$ and anti-ILl $\beta$ to animals with established arthritis significantly reduced inflammation, synovial infiltration, and cartilage destruction. Anti-ILl treatment restored the ability of chondrocytes to synthesise new cartilage matrix components.

\section{ROLE OF ILI IN HUMAN DISORDERS}

ILl is implicated in the aetiopathogenesis of several human diseases (table 1).

\section{Sepsis}

ILl levels are raised in infection, helping to recruit inflammatory cells to the infectious site. In cases of overwhelming infection, however, excessive or sustained ILl production may cause hypotension, multiorgan failure, hypoalbuminuria, and neutrophilia and contribute to the mortality associated with sepsis. ${ }^{27}$ In an evaluation of 15 patients with septic shock, plasma IL1 $\beta$ concentrations averaged $120 \mathrm{pg} / \mathrm{ml}$, which was two times higher than the levels found in a group of healthy volunteers. ${ }^{28}$ However, plasma ILI $\beta$ did not correlate with disease severity or mortality risk. In comparison, plasma TNF $\alpha$ was also significantly raised in the patients with septic shock, and these levels correlated with disease severity based on APACHE scores. Plasma levels of the two cytokines were unrelated.

\section{Rheumatoid arthritis}

As noted previously, plasma and synovial fluid concentrations of ILl $\beta$ are raised in patients with RA, and they correlate with disease activity and histological features. ${ }^{18}{ }^{19}$ Moreover, expression of high concentrations of human ILl $\beta$ in a rabbit knee joint produced clinical and histological features characteristic of RA. ${ }^{29}$ These features included synovial hypertrophy and hyperplasia; profound increases in leucocyte infiltration; high levels of cartilage breakdown products in joint fluid; reduced synthesis of extracellular matrix components; and systemic manifestations, such as fever, raised erythrocyte sedimentation rate (ESR), and weight loss. Histological analysis showed that the synovium had attached to cartilage and subchondral bone within the first week of ILl $\beta$ overexpression, and initial evidence of cortical bone erosion was seen at this time. In the second week, pannus invasion of cartilage and subchondral bone resulted in severe erosions of cortical bone, and thereafter, the pannus encroached into the bone marrow.

\section{Atherosclerosis}

Chronic inflammatory cells are found in the adventitia and media of abdominal aortic aneurysms as well as aortic occlusive disease. Infrarenal aortic biopsy specimens obtained from surgical patients with these conditions showed substantially higher ILl $\beta$ production than specimens obtained from cadaveric donors. ${ }^{30}$ ILl $\beta$ production averaged $908 \mathrm{pg} / \mathrm{ml}$ and 604 $\mathrm{pg} / \mathrm{ml}$ for specimens from patients with abdominal aortic aneurysm and aortic occlusive disease, respectively, as compared with $100 \mathrm{pg} / \mathrm{ml}$ for the specimens from the cadaveric donors. Lipopolysaccharide augmented ILI $\beta$ production in a concentration dependent manner, with maximal effects achieved at a concentration of $5 \mu \mathrm{g} / \mathrm{ml}$. In contrast, TNF $\alpha$ production was low in all aortic specimens, and lipopolysaccharide did not stimulate it. These findings suggest that inflammatory infiltrates found in patients with abdominal aortic aneurysms or aortic occlusive disease produce ILI $\beta$, which probably contributes to the underlying pathological sequelae.

\section{Alzheimer's disease}

ILl has been thought to have a role in Alzheimer's disease on the basis of its overexpression in the brains of afflicted

Table 1 Interleukin-1 (IL1) in the aetiopathogenesis of human disease

\begin{tabular}{|c|c|c|}
\hline $\begin{array}{l}\text { Strength of } \\
\text { evidence }\end{array}$ & Disease & $\begin{array}{l}\text { Evidence from clinical trials and in vitro } \\
\text { experiments }\end{array}$ \\
\hline Definite & 1 Rheumatoid arthritis & $\begin{array}{l}\text { ILIRa in the treatment of RA alone and in } \\
\text { combination with methotrexate }\end{array}$ \\
\hline Probable & $\begin{array}{l}1 \text { Septic shock } \\
2 \text { Graft versus host disease }\end{array}$ & $\begin{array}{l}\text { Mixed results from } 4 \text { studies using ILIRa } \\
\text { Preliminary results with ILIRa promising }\end{array}$ \\
\hline Experimental & $\begin{array}{l}2 \text { Arteriosclerosis } \\
3 \text { Adult T cell leukaemia } \\
4 \text { Multiple myeloma } \\
5 \text { Asthma }\end{array}$ & $\begin{array}{l}\text { In vitro studies showing overexpression of ILI and } \\
\text { increased risks in subjects with ILI } \alpha \text { allele } 2 \\
\text { polymorphism } \\
\text { Higher levels of IL } 1 \beta \text { in the aorta of patients with } \\
\text { aortoiliac occlusive disease and aneurysms } \\
\text { Increased ILI receptors on T cells } \\
\text { Homing of myeloma cells to marrow and osteolytic } \\
\text { lesions typical of biological actions of IL } 1 \\
\text { IL } 1 \beta \text { levels higher in asthma than in normal controls }\end{array}$ \\
\hline
\end{tabular}


patients; its ability to induce excessive expression of the $\beta$-amyloid precursor protein; and its ability to activate astrocytes to produce a number of important proteins related to Alzheimer's disease, including S100ß, IL6, $\alpha_{1}$ antichymotrypsin, and apolipoprotein E. ${ }^{31}$ Notably, the number of activated microglia that overexpress ILl has been correlated with the number of $\beta$-amyloid plaques. ${ }^{32}$ Moreover, a specific ILl $\alpha$ gene polymorphism in allele 2 appears to triple the risk of Alzheimer's disease, with the onset of disease occurring at an earlier age. ${ }^{33} \mathrm{~A}$ further increase in risk is seen in patients carrying allele 2 polymorphisms in both the ILl $\alpha$ and ILl $\beta$ genes.

\section{Cancer}

The transformation of normal cells into malignant ones is a multifactorial process that very probably occurs over many years. ILl may have a facilitative role in the process of tumorigenesis, inasmuch as it stimulates the proliferation of some tumour cells. For example, human ILl $\alpha$ and ILI $\beta$ stimulated the proliferation of adult $\mathrm{T}$ cell leukaemia cells that were freshly isolated from patients with leukaemia. ${ }^{34}$ These cells contained higher levels of ILl receptor than normal T cells. Notably, the growth of these freshly isolated leukaemia cells appeared to depend on an autocrine effect of ILl $\alpha$, because proliferation was suppressed by the addition of anti-ILl $\alpha$. In multiple myeloma, the biological actions of ILl are consistent with clinical features of disease, including osteolytic bone lesions and homing of myeloma cells to the bone marrow. ${ }^{35} \mathrm{It}$ remains to be determined whether ILl production in a pre-myeloma state is a critical factor in progression to active myeloma.

\section{Asthma}

The ability of ILl to stimulate granulocytes, lymphocytes, endothelial cells, epithelial cells, and haemopoietic cells is of potential relevance to the aetiology of asthma. ILI $\beta$ levels found in the bronchoalveolar lavage fluid of patients with symptomatic asthma were higher than those found in normal volunteers as well as asymptomatic patients. ${ }^{36}$ Moreover, expression of both ILI $\beta$ and ILIRa in bronchial epithelium of patients with asthma was significantly raised relative to healthy volunteers. ${ }^{37}$ Notably, the percentage of macrophages that produced ILI $\beta$ was significantly higher in the submucosa of patients with asthma than volunteers.

\section{EFFICACY OF BLOCKING ILI IN VARIOUS DISORDERS}

The activity of ILl may be reduced by several distinct pharmacological interventions-some are non-selective, such as fish oils and corticosteroids, whereas others selectively target ILl, such as anakinra and sILIR. To date, anakinra is the only selective intervention that has been shown in controlled clinical trials to be effective and well tolerated in the treatment of a specific human disorder, RA.

\section{Non-selective interventions}

Fish oil

The production of ILl as well as TNF $\alpha$ by peripheral blood mononuclear cells of healthy volunteers was reduced by a six week dietary supplementation with the n-3 polyunsaturated fatty acids found in a fish oil concentrate. ${ }^{38}$ Notably, production of these cytokines remained diminished even 10 weeks after the end of the supplementation period, but returned to baseline by 20 weeks. It should be recognised that the fish oil supplement also impacts other proinflammatory mediators, including cyclo-oxygenase and lipoxygenase products. The clinical benefit of a fish oil supplement in RA has been shown in a study in which 49 patients with RA were randomly allocated to receive high or low doses of eicosopentaenoic acid and docosohexanoic acid with a third group using olive oil as a control in prospective double blind trial for 24 weeks. ${ }^{39}$ Significant improvements from baseline were found in the number of tender joints (low dose $\mathrm{p}=0.05$, high dose group $\mathrm{p}=0.02$ ) and swollen joints (low dose $\mathrm{p}=0.001$, high dose $p=0.02$ ). Twenty one of 45 clinical parameters in the high dose fish oil group improved compared with eight in the low dose and five in the olive oil group during the study $(p=0.0002)$. Neutrophil leucotriene B4 and macrophage ILl production decreased significantly in both the low and high dose fish oil groups.

\section{Corticosteroids}

These agents are widely used in a variety of human diseases, including RA, asthma, inflammatory bowel disease, and cancer. Although the exact mechanism(s) responsible for the therapeutic benefit of corticosteroids in each clinical disorder is unclear, it is well recognised that these agents suppress ILI production. Glucocorticoids may also produce their antiinflammatory and immunosuppressive actions by augmenting the expression of ILIRII, the decoy receptor for ILl, and prolonging its half life..$^{40}$ Incubation of human neutrophils with $0.1 \mu \mathrm{M}$ dexamethasone led to a three- to sixfold increase in ILl $\beta$ binding, which reflected binding to the decoy receptor as confirmed by a surface affinity, cross linking analysis. In addition, dexamethasone induced the release of soluble ILl receptors from the neutrophils, representing an additional source of ILl buffering.

\section{Other chemical agents}

Although it is unlikely that ILl and its receptor effects could account for all of the antirheumatic properties of methotrexate, it has been shown that methotrexate blocks the binding of this cytokine to its receptor and hence would have the property of inhibiting cellular responses to IL $1{ }^{41}$ Further, there is emerging evidence that ILl may be involved in osteoarthritis (OA) tissue degradation. This has led to experimental observations of a new class of agents (diacerhein and rhein) and their beneficial effect on ILl/ILIR systems at the cartilage and synovial level in OA. ${ }^{42} 43$ Further, aceclofenac, a nonsteroidal anti-inflammatory drug (NSAID) that inhibits prostaglandin $\mathrm{E}_{2}\left(\mathrm{PGE}_{2}\right)$ synthesis, has been shown in ex vivo studies with $\mathrm{OA}$ tissues to modulate $\mathrm{PGE}_{2}$ production by decreasing nitric oxide synthesis and increasing ILlRa production in human articular chondrocytes. ${ }^{44}$

\section{Other cytokines}

Several cytokines may exert anti-inflammatory and immunoregulatory effects that counteract the biological actions of ILl. For example, pretreatment of human peripheral monocytes with interferon $\alpha$ or interferon $\gamma$ blocked subsequent ILl induced prostaglandin release..$^{45}$ Similarly, IL10 is effective in blocking the in vitro effects of ILl, but more importantly, it is effective in a variety of animal models that are dependent on ILl, including collagen induced arthritis. ${ }^{46}$ In a phase I study, an intravenous bolus injection of IL10 at $1-25 \mu \mathrm{g} / \mathrm{kg}$ reduced both ILl and TNF $\alpha$ production by blood cells, caused transient neutrophilia and monocytosis, and lowered lymphocyte counts, particularly those expressing T cell surface markers. ${ }^{47}$ In an early clinical trial of patients with RA, recombinant ILI0 was well tolerated and showed a trend towards being effective.

\section{Selective interventions}

\section{Anti-IL1 monoclonal antibody}

The use of neutralising antibodies to ILl $\alpha$ or ILl $\beta$, has not been evaluated in a clinical setting. Nevertheless, this intervention is effective in animal models of disease, such as collagen induced arthritis, as described in a previous section.

Soluble IL 1 receptor

The effect of soluble recombinant ILIRI was evaluated in healthy volunteers given an experimental endotoxin 


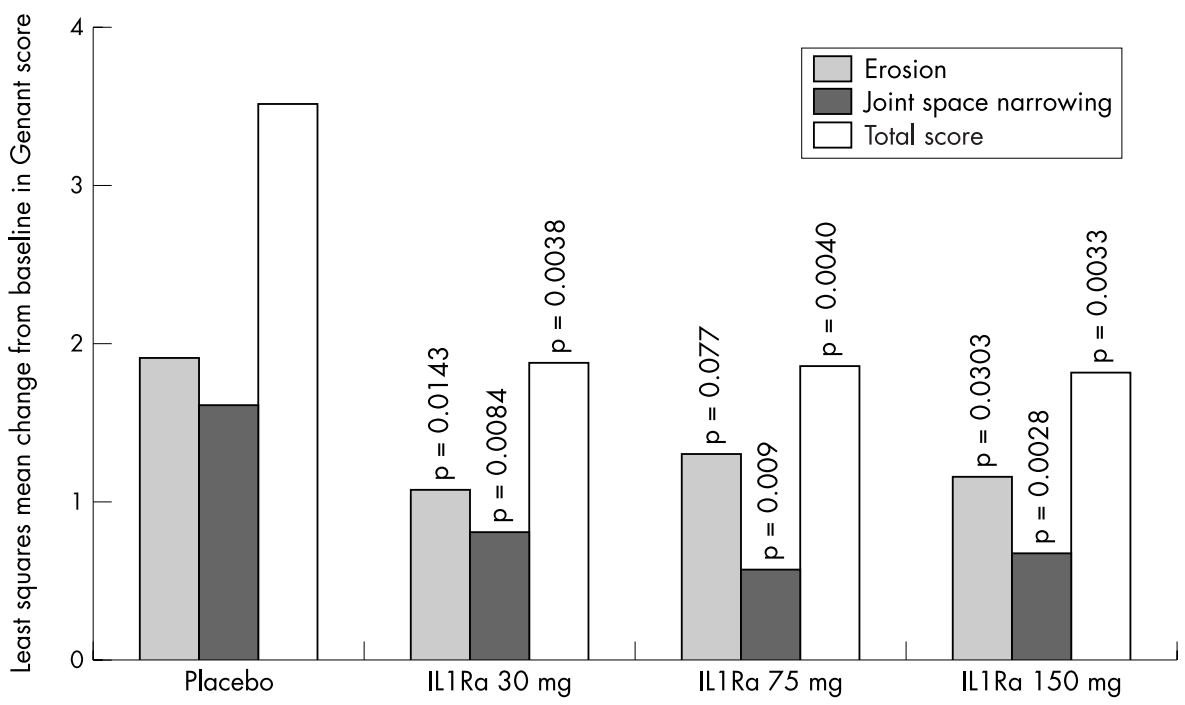

Figure 2 Effect of ILIRa on radiographic progression of RA. Serial hand radiographs at baseline and after 24 weeks were evaluated by the Genant method for patients treated with placebo ( $n=78)$ or ILIRa $30 \mathrm{mg}(\mathrm{n}=86), 75 \mathrm{mg}(\mathrm{n}=83)$, or $150 \mathrm{mg}(\mathrm{n}=79)$. Statistical significance versus placebo is shown above each histogram. From Jiang Y, Genant HK, Watt I, Cobby M, Bresnihan B, Aitchison R, et al. A multicenter, double-blind, dose-ranging, randomized, placebo-controlled study of recombinant human interleukin-1 receptor antagonist in patients with rheumatoid arthritis: radiologic progression and correlation of Genant and Larsen scores. Arthritis Rheum 2000;43: 1001-9. Copyright (c) 2000 Wiley-Liss Inc. Reprinted by permission of Wiley-Liss, Inc, a subsidiary of John Wiley \& Sons, Inc.

infusion. ${ }^{48}$ Soluble ILIRI significantly reduced ILI $\beta$ concentrations, but it also significantly reduced ILlRa levels. Notably, at a high dose, soluble ILIRI was associated with significantly raised levels of TNF $\alpha$, IL8 cell-associated ILI $\beta$, and C reactive protein (CRP). Although treatment reduced the severity of chills, soluble ILlRI did not alter the endotoxin induced changes in body temperature, systemic haemodynamics, or leucocyte or platelet counts. The increase in inflammatory mediators and absence of a discernable anti-inflammatory effect may be due to the neutralisation of IL1Ra by soluble ILlRI treatment.

\section{Anakinra}

Early clinical studies with anakinra focused on endotoxaemia, septic shock, and steroid resistant graft versus host disease. Infusion of anakinra significantly reduced endotoxin induced neutrophilia in a study of 14 healthy male volunteers; however, other endotoxin induced symptoms, including fever and tachycardia, were unaffected. ${ }^{49}$ Plasma cytokine levels were reduced non-significantly with anakinra treatment in this study. Anakinra infusion reduced 28 day mortality of patients with sepsis syndrome in a phase II, dose finding, open label study of 99 patients. ${ }^{50}$ However, in two large, double blind, placebo controlled multicentre trials, anakinra treatment did not provide a significant survival advantage for patients with sepsis syndrome or septic shock..$^{51}{ }^{52}$ In a preliminary evaluation of 17 patients with steroid resistant graft versus host disease after bone marrow transplantation, anakinra infusion led to an improvement in acute disease of at least one grade in $63 \%$ of evaluable patients. ${ }^{53}$ Complete resolution occurred in two patients during anakinra treatment and in an additional patient after treatment.

The feasibility of delivering anakinra by subcutaneous injection to patients with RA was demonstrated in a three week dose ranging and dose frequency study. ${ }^{54}$ Once daily administration was well tolerated and showed better clinical activity than dosing every three or seven days. These findings prompted a clinical evaluation of anakinra monotherapy in patients with active RA. ${ }^{14}$ In this multicentre study, 472 patients with disease duration for $0.5-8$ years were randomly assigned to receive anakinra $30 \mathrm{mg}, 75 \mathrm{mg}$, or $150 \mathrm{mg}$ or placebo once daily by subcutaneous injection for 24 weeks. Patients discontinued any previous disease modifying antirheumatic drug treatment before starting anakinra, but they were allowed to continue to receive NSAIDs and corticosteroids. Patients who completed the initial 24 week treatment were eligible to continue receiving ILIRa for a second 24 week period.

The primary efficacy variable was the ACR $20 \%$ composite index. ${ }^{55}$ After 24 weeks, IL1Ra $150 \mathrm{mg}$ enabled a significantly greater percentage of patients to achieve this level of clinical response as compared with placebo $(43 \% \vee 27 \%$; $p=0.014)$. In addition, treatment with any anakinra dose was significantly more effective than placebo $(p=0.020)$. The benefit of anakinra treatment was evident on all measures in the ACR composite index, including swollen and tender joint counts, patient and doctor global assessments, pain, disability, ESR, and CRP.

Also in this study, hand $x$ ray pictures were taken at baseline and after 24 weeks of treatment, and evaluated by the Genant and Larsen methods (fig 2). ${ }^{56}$ According to the Genant evaluation, radiographic progression was significantly slowed by any anakinra treatment as compared with placebo $(p=0.0004)$, with benefits evident on both bone erosions $(\mathrm{p}=0.0097)$ and joint space narrowing $(\mathrm{p}=0.0003)$ (fig 2$)$. In the Larsen evaluation, the erosive joint count was significantly reduced by any anakinra treatment as compared with placebo $(p=0.0005)$. The benefit of anakinra on joint space narrowing was maintained during the 24 week extension period, but a further slowing of erosions became evident during this period with continued anakinra treatment.

Anakinra was evaluated in combination with methotrexate in another 24 week, double blind, placebo controlled, multicentre study of patients with RA. ${ }^{15}$ This study included 419 patients who had active RA despite receiving methotrexate for at least six months, including stable weekly doses of 12.5-25 mg for the past three months before enrolment. Patients were randomly assigned to receive placebo or one of five different daily doses of anakinra: $0.04,0.1,0.4,1.0$, or 2.0 $\mathrm{mg} / \mathrm{kg}$. All patients continued to receive their regular methotrexate dose. After 24 weeks, anakinra treatment produced significantly higher ACR 20 response rates than placebo $(\mathrm{p}=0.0036)$. The anakinra $1.0 \mathrm{mg} / \mathrm{kg}$ group had the highest response rate $(42 \%)$, which was significantly greater than the $23 \%$ response rate with placebo $(p=0.021$ ) (fig 3 ). In addition, the two highest anakinra doses significantly reduced 


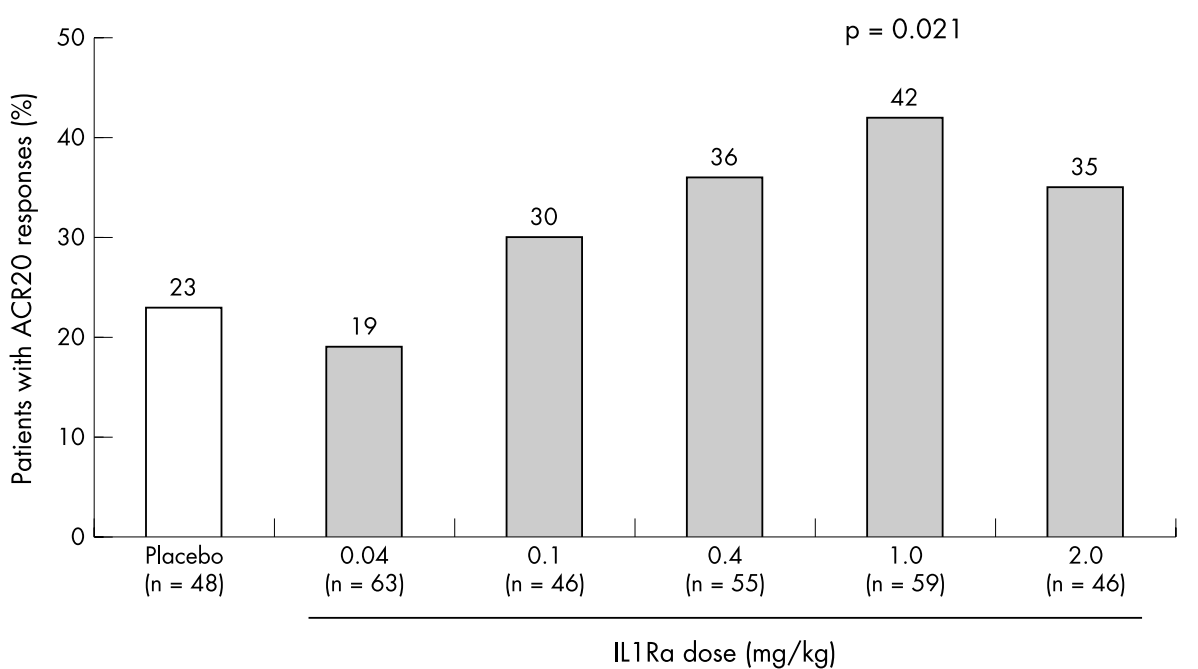

Figure 3 Effect of combination ILIRa and methotrexate treatment versus methotrexate alone on ACR $20 \%$ response rates after 24 weeks of treatment. From Cohen S, Hurd E, Cush JJ, et al. Treatment with interleukin-1 receptor antagonist in combination with methotrexate (MTX) in rheumatoid arthritis (RA) patients [abstract]. Arthritis Rheum 1999;42(suppl):S273. Copyright (C) 1994 Wiley-Liss Inc. Reprinted by permission of Wiley-Liss, Inc, a subsidiary of John Wiley \& Sons, Inc.

disability as determined by the Health Assessment Questionnaire $(\mathrm{p}<0.01)$.

\section{SAFETY OF ILIRa}

ILIRa has been generally safe and well tolerated when given by continuous infusion to healthy volunteers and patients with septic syndrome or by daily subcutaneous injection to patients with RA. In a phase I study, administration of anakinra to healthy men by a three hour continuous intravenous infusion at doses of between 1 and $10 \mathrm{mg} / \mathrm{kg}$ did not produce clinically significant changes in complete blood counts, mononuclear cell phenotypes, blood chemistry profiles, or serum iron or cortisol levels. ${ }^{57}$ In patients with steroid resistant acute graft versus host disease, anakinra was given by a continuous intravenous infusion at doses of 400-3200 mg daily for seven days. A reversible rise of liver transaminases was seen in two of 17 patients, but the enzyme levels returned to normal after completion of anakinra treatment. ${ }^{53}$ In patients with severe sepsis, anakinra was delivered by a $100 \mathrm{mg}$ intravenous bolus followed by a 72 hour continuous infusion at a rate of 2 $\mathrm{mg} / \mathrm{kg} / \mathrm{h}$. Clinical and laboratory adverse event rates were comparable for the ILIRa and placebo groups. ${ }^{52}$ The frequency of microbial superinfections was not increased by anakinra treatment, nor was the resolution of infection delayed by such treatment when appropriately covered by antibiotics.

In RA, monotherapy with anakinra was delivered by a daily subcutaneous injection at doses of $30 \mathrm{mg}, 75 \mathrm{mg}$, or $150 \mathrm{mg}{ }^{14}$ Injection site reactions were the most common adverse event, occurring in $50 \%, 73 \%$, and $81 \%$ of patients at the three respective anakinra doses as compared with $25 \%$ of patients in the placebo group. These events were generally mild, usually characterised by some erythema and induration, and usually resolved after 2-3 weeks. At the highest anakinra dose, 5\% of patients withdrew owing to injection site reactions as compared with $1-3 \%$ in the other groups (fig 4). Infections and allergic reactions occurred at a comparable rate in the anakinra and placebo groups. When anakinra was given in combination with methotrexate, injection site reactions were again the most common adverse event, occurring in $63 \%$ of patients receiving the highest anakinra dose $(2 \mathrm{mg} / \mathrm{kg})$ as

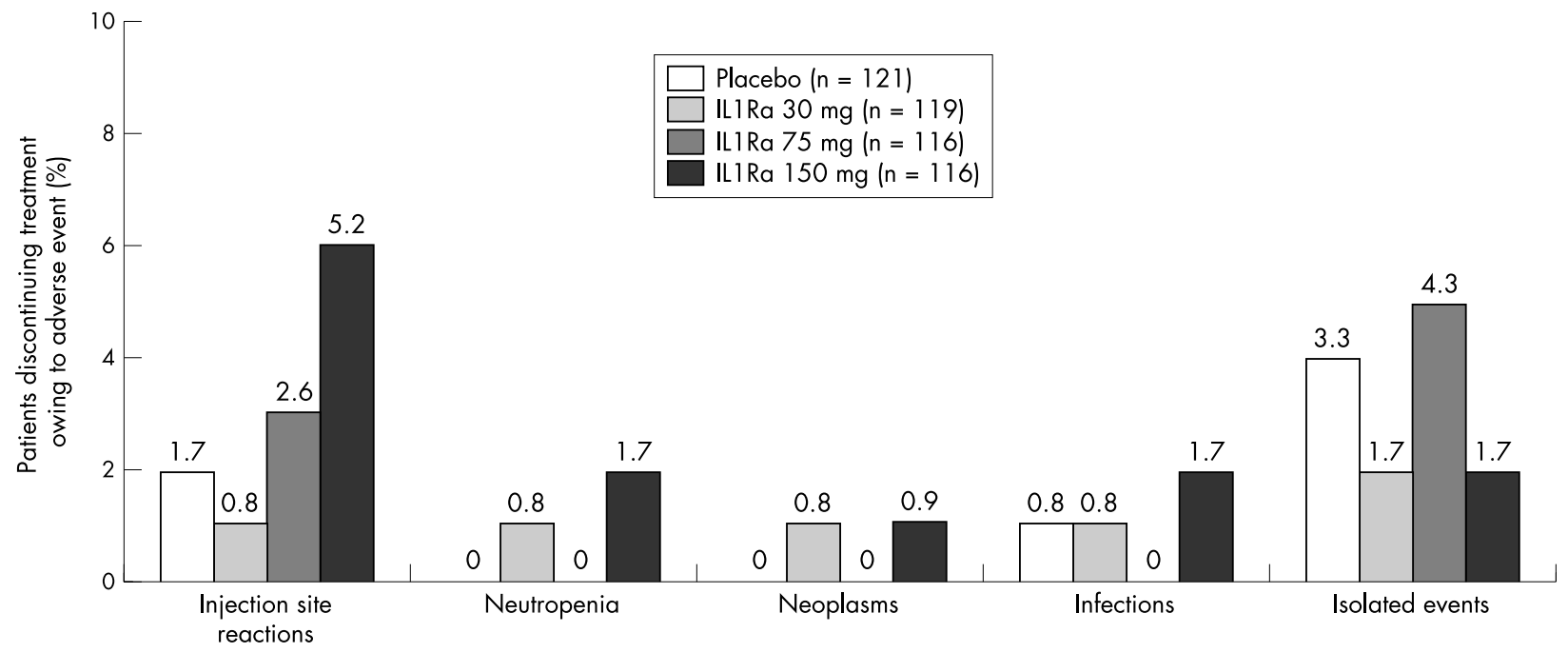

Figure 4 Distribution of withdrawals due to adverse events with ILIRa and placebo in patients with RA. From Bresnihan B, Alvaro-Gracia JM, Cobby M, Doherty M, Domljan Z, Emery P, et al. Treatment of rheumatoid arthritis with recombinant human interleukin-1 receptor antagonist. Arthritis Rheum 1998;41:2196-204. Copyright () 1998 Wiley-Liss Inc. Reprinted by permission of Wiley-Liss, Inc, a subsidiary of John Wiley \& Sons, Inc. 
compared with $19 \%$ with placebo (fig 4 ). ${ }^{58}$ In these groups, the withdrawal rate due to injection site reactions was $10 \%$ and $3 \%$, respectively. Other adverse events, including infections, were reported at a comparable rate with anakinra and placebo.

The Anakinra safety database, presented in public forum at the FDA Arthritis Advisory Committee in August 2001, has generally revealed an acceptable profile for just under 3000 subjects who have participated in controlled clinical trials. ${ }^{59-64}$ The incidence of serious infections appears to be higher $(1.8 \%$ $v 0.7 \%$ ) in all patients receiving the $100 \mathrm{mg}$ daily dose. ${ }^{63}{ }^{64}$ This figure is largely driven by a safety study of 1400 patients where serious infections (those requiring admission to hospital) were noted in $2.1 \%$ of anakinra subjects compared with $0.4 \%$ of controls. ${ }^{60}$ Post hoc analysis of risk factors for serious infection in this study indicates that risk is higher in anakinra subjects either receiving corticosteroids or with a history of asthma or pneumonia.

There is limited information available on the safety of anakinra taken with other biological agents. A small open label 24 week study of anakinra employed upon a background of etanercept treatment showed serious infections in $7 \%$ of the 58 patient combination study; leucopenia was seen more frequently, and two patients with neutrophil counts below 1000/ $\mathrm{mm}^{3}$ developed subsequent serious infections. ${ }^{616364}$ The current package insert for anakinra urges extreme caution in the use of anakinra in combination with TNF inhibitors. ${ }^{62}$ To date there have been no reports of reactivation tuberculosis for anakinra subjects in clinical trials.

\section{CONCLUSION}

A large body of experimental evidence implicates ILl in the pathogenesis of a variety of human disorders. Many therapeutic interventions either directly or indirectly reduce the biological activities of ILl, and some of these agents, including anakinra, anti-ILl, and SILIR, were effective in a wide range of animal disease models. Nevertheless, translation of these promising preclinical observations into the clinical setting has been a difficult undertaking. On the basis of controlled clinical trials with anakinra, it is now evident that blocking the effects of ILl contributes to reduction in the symptoms of RA. Treatment with anakinra slowed radiographic disease progression. Moreover, addition of anakinra to existing methotrexate treatment safely reduced signs and symptoms of active disease. Nevertheless, preliminary observations from a small open study on the concomitant use of anakinra with biological induced TNF blockade indicate extreme caution should be exercised until larger and more definitive studies are available. These studies illustrate the clinical use of anakinra in the management of RA. The role of anakinra in the treatment of other disorders, in which ILl has been implicated to be of pathogenic relevance, still needs to be defined by controlled clinical investigations. Finally, the long term effects of ILl blockade, especially in combination with other biological agents, need to be evaluated, particularly its safety, because these diseases are chronic and continuous treatment will be required.

\section{ACKNOWLEDGEMENT}

Grant provided by Amgen Inc.

\section{Authors' affiliations}

D S Hallegua, M H Weisman, Cedars-Sinai Medical Center/UCLA School of Medicine, Los Angeles, CA 90048, USA

\section{REFERENCES}

1 Dinarello CA, Wolff SM. The role of interleukin-1 in disease. N Engl J Med 1993:328:106-13.

2 Dinarello CA. Biological basis for interleukin-1 in disease. Blood 1996;87:2095-147.
3 Fox DA. Cytokine blockade as a new strategy to treat rheumatoid arthritis: inhibition of tumor necrosis factor. Arch Intern Med 2000; 160:437-44

4 Papadakis KA, Targan SR. Tumor necrosis factor: biology and therapeutic inhibitors. Gastroenterology 2000;1 19:1148-57.

5 Moreland LW, Schiff MH, Baumgartner SW, Tindall EA, Fleischmann RM, BulpittKJ, et al. Etanercept therapy in rheumatoid arthritis. A randomized, controlled trial. Ann Intern Med 1999;130:478-86.

6 Weinblatt ME, Kremer JM, Bankhurst AD, Bulpitt KJ, Fleischmann RM, Fox RI, et al. A trial of etanercept, a recombinant tumor necrosis factor receptor: Fc fusion protein, in patients with rheumatoid arthritis receiving methotrexate. N Engl J Med 1999:340:253-9.

7 Bathon JM, Martin RW, Fleischmann RM, Tesser JR, Schiff MH, Keystone $\mathrm{EC}$, et al. A comparison of etanercept and methotrexate in patients with early rheumatoid arthritis. N Engl J Med 2000;343:1586-93.

8 Maini R, St Clair EW, Breedveld F, Furst D, Kalden J, Weisman M, et al. Infliximab (chimeric anti-tumour necrosis factor $\alpha$ monoclonal antibody) versus placebo in rheumatoid arthritis patients receiving concomitant methotrexate: a randomised phase III trial. Lancet 1999;354:1932-9.

9 Lipsky PE, van der Heijde DM, St Clair EW, Furst DE, Breedveld FC, Kalden JR, et al. Infliximab and methotrexate in the treatment of rheumatoid arthritis. Anti-Tumor Necrosis Factor Trial in Rheumatoid Arthritis with Concomitant Therapy Study Group. N Engl J Med 2000;343:1594-602

10 Moreland LW, Cohen SB, Baumgartner SW, Tindall EA, Bulpitt K, Martin R, Weinblatt $M$, et al. Long-term safety and efficacy of etanercept in patients with rheumatoid arthritis. J Rheumatol 2001;28:1238-44.

11 Targan SR, Hanauer SB, van Deventer SJ, Mayer L, Present DH, Braakman T, et al. A short-term study of chimeric monoclonal antibody cA2 to tumor necrosis factor $\alpha$ for Crohn's disease. N Engl J Med 1997;337:1029-35.

12 Rutgeerts P, D'Haens G, Targan S, Vasiliauskas E, Hanauer SB, Present $\mathrm{DH}$, et al. Efficacy and safety of retreatment with anti-tumor necrosis factor antibody (infliximab) to maintain remission in Crohn's disease. Gastroenterology 1999;1 17:761-9.

13 Present DH, Rutgeerts P, Targan S, Hanauer SB, Mayer L, van Hogezand RA, et al. Infliximab for the treatment of fistulas in patients with Crohn's disease. N Engl J Med 1999;340:1398-405.

14 Bresnihan B, Alvaro-Gracia JM, Cobby M, Doherty M, Domlian Z, Emery $\mathrm{P}$, et al. Treatment of rheumatoid arthritis with recombinant human interleukin-1 receptor antagonist. Arthritis Rheum 1998:41:2196-204.

15 Cohen S, Hurd E, Cush JJ, Schiff M, Weinblatt ME, Moreland LW, et al. Treatment with interleukin-1 receptor antagonist in combination with methotrexate (MTX): results of a twenty-four-week, multicenter, randomized, double-blind, placebo-controlled trial. Arthritis Rheum 2002;46:614-24

16 Arend WP, Malyak M, Guthridge CJ, Gabay C. Interleukin-1 receptor antagonist: role in biology. Annu Rev Immunol 1998; 16:27-55.

17 Dianarello CA. Role of interleukin-1 and tumor necrosis factor in systemic responses to infection and inflammation. In: Gallin JI, Goldstein IM, Snyderman R, eds. Inflammation: basic principles and clinical correlates. 2nd ed. New York: Raven Press; 1992:211-32.

18 Eastgate JA, Symons JA, Wood NC, Grinlinton FM, di Giovine FS, Duff GW. Correlation of plasma interleukin 1 levels with disease activity in rheumatoid arthritis. Lancet 1988;2:706-8.

19 Kahle P, Saal JG, Schaudt K, Zacher J, Fritz P, Pawelec G. Determination of cytokines in synovial fluids: correlation with diagnosis and histomorphological characteristics of synovial fluid. Ann Rheum Dis 1992;51:731-4.

20 Chikanza IC, Roux-Lombard P, Dayer JM, Panayi GS. Dysregulation of the in vivo production of interleukin-1 receptor antagonist in patients with rheumatoid arthritis. Pathogenetic implications. Arthritis Rheum $1995 ; 38: 642-8$

21 Chomarat P, Vannier E, Dechanet J, Rissoan MC, Banchereau J, Dinarello CA, et al. Balance of IL-1 receptor antagonist/IL-1 $\beta$ in rheumatoid synovium and its regulation by IL-4 and IL-10. J Immunol 1995; 154:1432-9

22 Horai R, Saijo S, Tanioka H, Nakae S, Sudo K, Okahara A, et al. Development of chronic inflammatory arthropathy resembling rheumatoid arthritis in interleukin 1 receptor antagonist-deficient mice. J Exp Med 2000:191:313-20.

23 Nicklin MJ, Hughes DE, Barton JL, Ure JM, Duff GW. Arterial inflammation in mice lacking the interleukin 1 receptor antagonist gene. Exp Med 2000;191:303-12.

24 Cominelli F, Nast CC, Duchini A, Lee M. Recombinant interleukin-1 receptor antagonist blocks the proinflammatory activity of endogenous interleukin-1 in rabbit immune colitis. Gastroenterology 1992; 103:65-71.

25 Ferretti M, Casini-Raggi V, Pizarro TT, Eisenberg SP, Nast CC, Cominelli F. Neutralization of endogenous IL-1 receptor antagonist exacerbates and prolongs inflammation in rabbit immune colitis. I Clin Invest 1994;94:449-53.

26 Van den Berg WB, Joosten LAB, Helsen M, van de Loo FAJ. Amelioration of established murine collagen-induced arthritis with anti-ILtreatment. Clin Exp Immunol 1994;95:237-43

27 Pruitt JH, Copeland EM III, Moldawer LL. Interleukin-1 and interleukin-1 antagonism in sepsis, systemic inflammatory response syndrome, and septic shock. Shock 1995;3:235-51

28 Cannon JG, Tompkins RG, Gelfand JA, Michie HR, Stanford GG, van der Meer JW, et al. Circulating interleukin-1 and tumor necrosis factor in septic shock and experimental endotoxin fever. J Infect Dis 1990; 161:79-84. 
29 Ghivizzani SC, Kang R, Georgescu HI, Lechman ER, Jaffurs D, Engle JM, et al. Constitutive intra-articular expression of human IL-1 $\beta$ following gene transfer to rabbit synovium produces all major pathologies of human rheumatoid arthritis. J Immunol 1997; 159:3604-12.

30 Pearce WH, Sweis I, Yao JS, McCarthy WJ, Koch AE. Interleukin-1 $\beta$ and tumor necrosis factor- $\alpha$ release in normal and diseased human infrarenal aortas. J Vasc Surg 1992; 16:784-9.

31 Griffin WST, Nicoll JAR, Grimaldi LME, Sheng JG, Mrak RE. The pervasiveness of interleukin-1 in Alzheimer pathogenesis: a role for specific polymorphisms in disease risk. Exp Gerontol 2000;35:481-7.

32 Sheng JG, Mrak RE, Griffin WST. Interleukin-1 expression in brain regions in Alzheimer's disease: correlation with neuritic plaque distribution. Neuropathol Appl Neurobiol 1995;21:290-301.

33 Nicoll JA, Mrak RE, Graham DI, Stewart J, Wilcock G, MacGowan S, et al. Association of interleukin-1 gene polymorphisms with Alzheimer's disease. Ann Neurol 2000;47:365-8.

34 Shirakawa F, Tanaka Y, Oda S, Eto S, Yamashita U. Autocrine stimulation of interleukin $1 \alpha$ in the growth of adult human T-cell leukemia cells. Cancer Res 1989;49:1 143-7.

35 Lust JA, Donovan KA. The role of interleukin-1 beta in the pathogenesis of multiple myeloma. Hematol Oncol Clin North Am 1999;13:1117-25.

36 Broide DH, Lotz M, Cuomo AJ, Coburn DA, Federman EC, Wasserman SI. Cytokines in symptomatic asthma airways. J Allergy Clin Immunol 1992:89:958-67.

37 Sousa AR, Lane SJ, Nakhosteen JA, Lee TH, Poston RN. Expression of interleukin-1 beta (IL-1 $\beta$ ) and interleukin-1 receptor antagonist (IL-1 ra) on asthmatic bronchial epithelium. Am J Respir Crit Care Med 1996; 154:1061-6.

38 Endres S, Ghorbani R, Kelley VE, Georgilis K, Lonnemann G, van der Meer JW, et al. The effect of dietary supplementation with $n-3$ polyunsaturated fatty acids on the synthesis of interleukin-1 and tumor necrosis factor by mononuclear cells. N Engl J Med 1989;320:265-71.

39 Kremer JM, Lawrence DA, Jubiz W, DiGiacomo R, Rynes R, Bartholomew LE, et al. Dietary fish oil and olive oil supplementation in patients with rheumatoid arthritis. Clinical and immunologic effects. Arthritis Rheum 1990; 33:810-20

$40 \operatorname{Re}$ F, Muzio M, De Rossi M, Polentarutti N, Giri JG, Mantovani A, et al. The type II "receptor" as a decoy target for interleukin 1 in polymorphonuclear leukocytes: characterization of induction by dexamethasone and ligand binding properties of the released decoy receptor. J Exp Med 1994; 179:739-43.

41 Cronstein BN. The mechanism of action of methotrexate. Rheum Dis Clin North Am. 1997;23:739-55.

42 Martel-Pelletier J, Mineau F, Jolicoeur F-C, Cloutier J-M, Pelletier J-P. In vitro effects of Diacerhein and Rhein on interleukin 1 and tumor necrosis factor- $\alpha$ systems in human osteoarticular synovium and chondrocytes. J Rheumatol 1998;25:753-62.

43 Hochberg MC, Dougados M. Pharmacological therapy of osteoarthritis. Best Pract Res Clin Rheumatol 2001;15:583-93.

44 Maneiro E, Lopez-Armada M, Fernandez-Sueiro JL, Lema B, Galdo F, Blanco FJ. Aceclofenac increases the synthesis of interleukin 1 receptor antagonist and decreases the production of nitric oxide in human articular chondrocytes. J Rheumatol 2001;28:2692-9.

45 Browning JL, Ribolini A. Interferon blocks interleukin 1-induced prostaglandin release from human peripheral monocytes. J Immunol 1987; 138:2857-63

46 Keystone E, Wherry J, Grint P. IL-10 as a therapeutic strategy in the treatment of rheumatoid arthritis. Rheum Dis Clin North Am 1998;24:629-39.

47 Chernoff AE, Granowitz EV, Shapiro L, Vannier E, Lonnemann G, Angel $\mathrm{JB}$, et al. A randomized, controlled trial of IL-10 in humans. Inhibition of inflammatory cytokine production and immune responses. J Immunol 1995; 154:5492-9
48 Preas HL 2nd, Reda D, Tropea M, Vandivier RW, Banks SM, Agosti JM et al. Effects of recombinant soluble type I interleukin-1 receptor on human inflammatory responses to endotoxin. Blood 1996;88:2465-72.

49 Granowitz EV, Porat R, Mier JW, Orencole SF, Callahan MV, Cannon $J G$, et al. Hematologic and immunomodulatory effects of an interleukin-1 receptor antagonist coinfusion during low-dose endotoxemia in healthy humans. Blood 1993;82:2985-90.

50 Fisher CJ Jr, Slotman GJ, Opal SM, Pribble JP, Bone RC, Emmanuel G, et al. Initial evaluation of human recombinant interleukin-1 receptor antagonist in the treatment of sepsis syndrome: a randomized, open-label, placebo-controlled multicenter trial. Crit Care Med 1994;22:12-21.

51 Fisher CJ Jr, Dhainaut JF, Opal SM, Pribble JP, Balk RA, Slotman GJ, et al. Recombinant human interleukin-1 receptor antagonist in the treatment of patients with sepsis syndrome: results from a randomized, double-blind, placebo-controlled trial. JAMA 1994;271:1836-43.

52 Opal SM, Fisher CJ Jr, Dhainaut JF, Vincent JL, Brase R, Lowry SF, et al. Confirmatory interleukin-1 receptor antagonist trial in severe sepsis: a phase III, randomized, double-blind, placebo-controlled, multicenter trial. Crit Care Med 1997;25: 111 15-24.

53 Antin JH, Weinstein HJ, Guinan EC, McCarthy P, Bierer BE, Gilliland DG, et al. Recombinant human interleukin-1 receptor antagonist in the treatment of steroid-resistant graft-versus-host disease. Blood 1994;84:1342-8.

54 Campion GV, Lebsack ME, Lookabaugh J, Gordon G, Catalano M. Dose-range and dose-frequency study of recombinant human interleukin-1 receptor antagonist in patients with rheumatoid arthritis. Arthritis Rheum 1996;39:1092-101.

55 Felson DT, Anderson JJ, Boers M, Bombardier C, Chernoff M, Fried B, et al. The American College of Rheumatology preliminary core set of disease activity measures for rheumatoid arthritis clinical trials. Arthritis Rheum 1993:36:729-40.

56 Jiang Y, Genant HK, Watt I, Cobby M, Bresnihan B, Aitchison R, et al. A multicenter, double-blind, dose-ranging, randomized, placebo-controlled study of recombinant human interleukin-1 receptor antagonist in patients with rheumatoid arthritis: radiologic progression and correlation of Genant and Larsen scores. Arthritis Rheum 2000;43:1001-9

57 Granowitz EV, Porat R, Mier JW, Pribble JP, Stiles DM, Bloedow DC, et al. Pharmacokinetics, safety and immunomodulatory effects of human recombinant interleukin-1 receptor antagonist in health humans. Cytokine 1992;4:353-60.

58 Bresnihan B. The safety and efficacy of interleukin-1 receptor antagonist in the treatment of rheumatoid arthritis. Semin Arthritis Rheum 2001;30(suppl 2):17-20.

59 Cohen S, Moreland L, Cush J, Greenwalk MW, Block JA. Anakinra (recombinant interleukin-1 receptor antagonist): a large, placebo controlled efficacy trial of anakinra in patients with erosive rheumatoid arthritis disease [abstract]. Arthritis Rheum 2001;44(suppl):abstract LB-1.

60 Fleischmann R, Tesser J, Schechtman J, Modafferi D, Poulakos J. A safety trial of anakinra; recombinant interleukin-1 receptor antagonist (IL-1 ra), in a large, placebo controlled heterogeneous population of patients with rheumatoid arthritis. Arthritis Rheum 2001;44(suppl):S84.

61 Schiff M, Bulpitt K, Weaver A, Kazazi F, Joh T, Newmark R. Safety of combination therapy with anakinra and etanercept in patients with rheumatoid arthritis [abstract]. Arthritis Rheum 2001;44(suppl):S79.

62 Kineret (anakinra) package insert. Amgen Inc, 2001.

63 Clinical Review. Amgen, Biologic Licensing Application, STN 103950 anakinra for use in the treatment of rheumatoid arthritis. Prepared 9 July 92001.

64 Kineret (anakinra). FDA Arthritis Drugs Advisory Committee Briefing Package, Meeting Date: 16 August 2001, document date: 17 July 2001. 